\title{
Characterisation of naturally occurring radionuclides in the Lower Rhone River (France): preliminary results from suspended solid monitoring
}

\author{
M. Zebracki ${ }^{1}$, F. Eyrolle ${ }^{1}$, X. Cagnat $^{2}$, C. Antonelli ${ }^{1}$, \\ A. De Vismes-Ott ${ }^{2} \&$ V. Boullier ${ }^{1}$ \\ ${ }^{1}$ IRSN/LERCM, France \\ ${ }^{2}$ IRSN/LMRE, France
}

\begin{abstract}
Long term time series acquired in the frame of radioecological monitoring programmes are useful tools for exploring the variability of naturally occurring radionuclide contents. The data set was established in order to investigate the role of discharge, flood type and flood chronicles on such variability within the suspended sediments. Preliminary results show that radionuclide geochemical properties as well as suspended sediment nature and particle residence time may in some particular cases significantly affect the U-Th series nuclide equilibrium. Keywords: monitoring, radiological surveillance, aquatic environments, suspended sediments, radionuclides, Rhone River, uranium series, thorium series, naturally occurring radionuclides, floods.
\end{abstract}

\section{Introduction}

Radiological surveillance of the environment responds to a national concern and is consistent with a European approach to improve the quality of aquatic environments.

Long term time series of suspended solids and associated species in rivers acquired in the framework of monitoring programmes are useful tools to evaluate pollution levels, quantify fluxes towards marine environments and investigate mechanisms controlling the concentrations of various trace or major elements in rivers $[1,2]$. 
The Rhone River (South-East of France) is one of the largest rivers of the Mediterranean Sea. Its catchment area is characterized by great climatic and geological heterogeneity and the river has been under various anthropogenic influences for several decades (damming, river embankment, industrial and domestics effluents, and nuclear power plants). At the lower course of the river numerous studies have been dedicated to solid fluxes and associated contaminants with a particular emphasis on floods since such events have been shown to play a fundamental role on fluxes of suspended sediment [3-5], trace and major elements [2, 5, 6] and artificial radionuclides [7]. Studies also focused on sediment and contaminant storages and dynamics in alluvial margins [7-9], and allowed to assess the origins and subsequent levels of artificial radionuclides [10]. Concerning the Rhone River, only very scare data have been published for particle bound naturally occurring radionuclides and, to our knowledge, none refers to the soluble phase [11, 12].

In this context, one of our first research objectives is to explore the variability of naturally occurring radionuclide contents within the suspended particulate matter (SPM) in relation to the origins of floods and the hydrographical areas. This paper gives preliminary results on the fate and geochemical behaviour of some naturally occurring radionuclides from monitoring data chronicles acquired over the past twelve years.

\section{Study area and regional settings}

The Rhone River constitutes the main water discharge into the Mediterranean Sea and delivers more than $80 \%$ of the solid compound to the Gulf of Lion continental shelf (North western Mediterranean Sea) [13]. The Rhone River is $816 \mathrm{~km}$ length and its watershed spreads over $97800 \mathrm{~km}^{2}$ (Figure 1).

The Rhone watershed area is mainly characterised by four mountainous catchments: the Alps, the Jura, the Cevennes, and the Vosges. This large mountainous catchment is related to strong climatic and geological heterogeneity as described in $[2,5]$.

The Alpine mountains (Upper Rhone River, Isere and Durance watersheds) generally consist of sedimentary rocks and of siliceous crystalline and metamorphic rocks. On the north of the catchment, the Jura and Vosges mountains (Saone watershed) are mainly calcareous, while on the western part of the catchment, crystalline siliceous rocks dominate in the Cevennes mountains (Ardeche and Ceze watersheds).

The Rhone River's hydrological regime results from glacier-melt, snowmelt and rains [2] and is characterised by a consequent heterogeneity in water discharge due to the contrast in precipitations between mountains and plains. In the lower course of the Rhone River, there are four types of climatological regimes $[4,14]$ :

(1) Oceanic floods generally occurring in the winter and resulting from rains affecting the northern part of the river watershed (Fier, Ain, Isere, Saone); 
(2) Mediterranean floods mainly occurring in the autumn and resulting from stormy rains (flash-flood type) affecting the western tributaries of the river (Ardeche, Ceze, Gard, Eyrieux);

(3) Extensive Mediterranean floods resulting from precipitations affecting the western side of the river (Cevenol tributaries listed above) and the sub-alpine tributaries on the eastern part of the river (Durance, Ouveze and to a lesser extent the Drome);

(4) Generalized floods generally occurring in the autumn and combining the northern and southern tributaries.

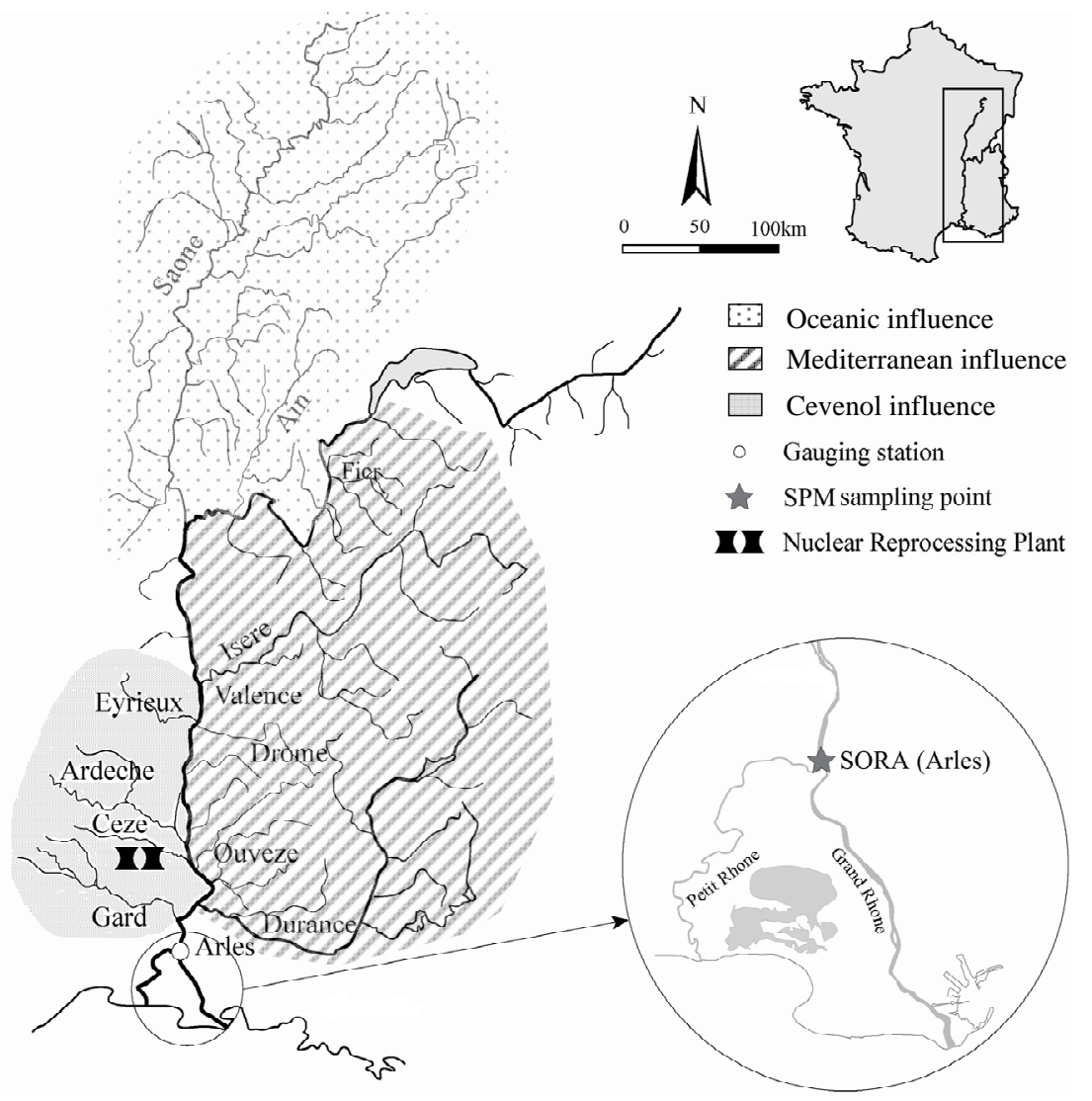

Figure 1: Catchment area of the Rhone River and sampling point location.

As a consequence of the heterogeneity of rainfall throughout the large catchment area, the water discharges and suspended solids concentrations display annual and inter-annual variability. The mean annual discharge is about $1700 \mathrm{~m}^{3} . \mathrm{s}^{-1}$ at the Beaucaire gauging station and the annual suspended load ranged from 1 to $19{\mathrm{Mt} . \mathrm{yr}^{-1}}$ over the $1967-2007$ period [3, 15]. The values for 
the 1-year, 2-year, 10-year, 50-year and 100-year return-period discharges are 4 000, 4 800, 8 400, 10400 and $11200 \mathrm{~m}^{3} . \mathrm{s}^{-1}$, respectively.

Sixty kilometres up from its mouth (delta of $1455 \mathrm{~km}^{2}$ ), the Rhone River splits into two unequal branches: the Grand Rhone River and the Petit Rhone River (Figure 1). Our sampling station in Arles is located $10 \mathrm{~km}$ down the diffluence of the Rhone River on the Grand Rhone River, which drains about $90 \%$ of the water discharge [16].

The Rhone River serves as an outlet for several industrial and domestic releases and for the low-level radioactive effluents from four nuclear power plants and one spent fuel reprocessing plant at present.

\section{Materials and methods}

\subsection{Discharge measurements}

Water discharge data is derived from fourteen gauging stations operated by the French company "Compagnie Nationale du Rhône” (CNR): at Beaucaire (total liquid discharge of the Rhone, downstream of the last confluence), at Arles (downstream the diffluence, $90 \%$ of the total liquid discharge), and at the downstream parts of the twelve main tributaries of the Rhone River: the Fier, Ain, Isere, Saone, Eyrieux, Drome, Ardeche, Ceze, Durance and Gard Rivers (Figure 1).

\subsection{Water and suspended solids sampling}

The Rhone River Observatory Station in Arles (SORA) is an automatic sampling station devoted to the environmental monitoring of radionuclides in the Rhone River and operated by the IRSN. The SORA sampling station is situated closed to the CNR water discharge gauging station. The SORA station has been in use in its current configuration since 2003, and the sampling procedures evolved in the framework of routine water quality monitoring [17] or for specific studies $[4,14]$. The current sampling scheme has been homogeneous since 2008 and water sample collection is described in detail in [12,17]. Briefly, punctual and time-integrated SPM and filtered water samples are automatically collected according to different sampling and analytical procedures, especially depending on whether the discharge is below or above the threshold of $3000 \mathrm{~m}^{3} . \mathrm{s}^{-1}$. This flood threshold was chosen based on previous work $[3,15]$ and is mainly associated with the observed significant breakdown in the relationship between the total suspended solid concentration and the discharge that demonstrate the beginning of sediment transport under flood conditions at this flow rate.

\subsection{Flood deposits}

Apart from suspended particulate matter monitoring at the lower course of the Rhone River, flood deposits have recently started to be collected within the alluvial margins of the main tributaries just after flooding in order to characterise the various watershed source terms. 


\subsection{Radionuclide analyses}

Gamma ray emissions were analysed by direct gamma spectrometry with Germanium Hyper-Pure detectors [18]. For the radionuclides from the U-238 series, Ra-226 specific activities were based on measurements of its decay chain descendant $\mathrm{Bi}-214$ and the assumption of secular equilibrium. The establishment of the radioactive equilibrium between Ra-226 and its short-lived daughters was assured by counting at least 24 days after hermetically enclosing the sample in radon tight containers [12]. Further on this time is sufficient for the radioactive equilibrium between the short-lived nuclides in the Th-232 series to be reached. All activities are reported in Bq. $\mathrm{kg}^{-1}$ of dry matter.

\section{Results and discussion}

\subsection{Data set and relevance}

Since 2000, about $85 \%$ of flood events that occurred at the lower course of the Rhone River have led to data acquisition though water samplings. Between 2000 and 2011, 385 samples dedicated to SPM analyses were collected, including 159 samples collected at low water discharge $\left(\mathrm{Q}<3000 \mathrm{~m}^{3} . \mathrm{s}^{-1}\right)$, and 226 samples collected for 35 flood events $\left(\mathrm{Q}>3000 \mathrm{~m}^{3} \cdot \mathrm{s}^{-1}\right)$. Figure 2 shows the distribution of samples collected during floods.

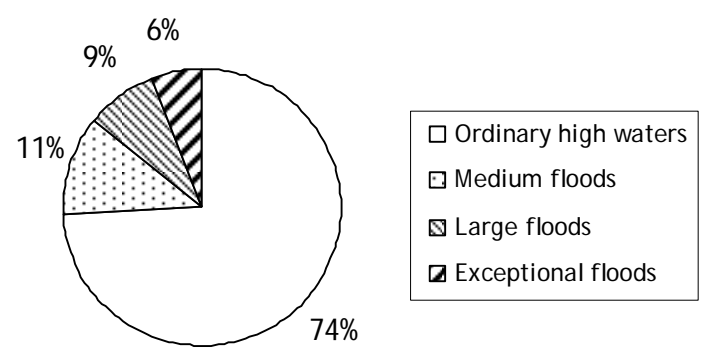

Figure 2: $\quad$ Sample distribution (\%) among flood discharge classifications.

This distribution is established by considering the mean maximal daily water discharge recorded during flood events and the following discharge classification: ordinary high discharges $\left(3000-4000 \mathrm{~m}^{3} \cdot \mathrm{s}^{-1}\right)$, medium floods $\left(4000-5000 \mathrm{~m}^{3} \cdot \mathrm{s}^{-1}\right)$, large floods $\left(5000-9000 \mathrm{~m}^{3} \cdot \mathrm{s}^{-1}\right)$, and exceptional floods (over $9000 \mathrm{~m}^{3} \cdot \mathrm{s}^{-1}$ ). Over the studied period, the major occurrence concerns, as expected, ordinary high discharges (74\%). Two exceptional floods were registered during autumn 2002 and winter 2003.Figure 3 shows the distribution of samples collected for each flood type: oceanic, Mediterranean, extensive Mediterranean and generalised. Thanks to the long-term data acquisition at Arles since 2000, the various flood types were sampled, leading to relevant data that cover the whole range of climatic regimes generating floods. Nine floods (i.e. $20 \%$ of the total sampled floods) are not currently defined as the 


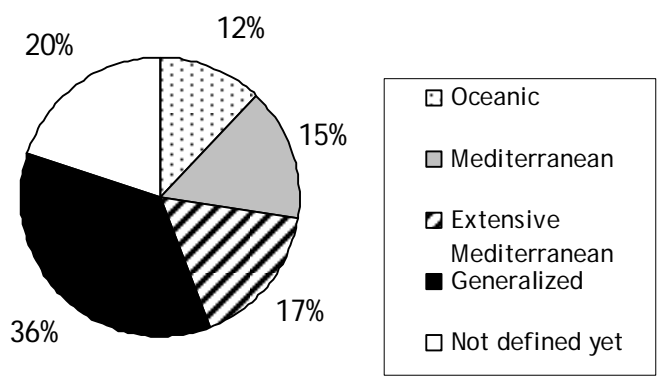

Figure 3: $\quad$ Sample distribution (\%) among flood types.

hydrological dataset for the different tributaries is not still fully acquired. These additional data will enrich this preliminary dataset.

Regarding the radionuclide activity dataset, the available data depends on the radionuclides that were detected by gamma spectrometry measurements as part of them are under the limit of detection or not attainable (Table 1). Naturally occurring radionuclides activity dataset from monitoring shows that Th-234, $\mathrm{Pb}$ 210, Ac-228 and Be-7 were detected in more than $80 \%$ of cases. Pb-214, Bi-214, $\mathrm{Pb}-212, \mathrm{Bi}-212$ and $\mathrm{K}-40$ were only detected in $25 \%$ of cases. U-234, Pa-234 and Ra-226 have been very rarely detected (maximum $7 \%$ of cases). The number of available data in the particulate fraction is constrained by gammaspectrometry performance and low-level activities of naturally occurring radionuclides in freshwater environments.

Table 1: $\quad$ Radionuclides detected.

\begin{tabular}{|c|c|c|c|c|c|c|c|c|c|c|c|c|c|c|c|c|}
\hline & & & & & $\mathrm{U}-238$ & & & & & & Th-232 & & & & & \\
\hline & & Th- & Pa- & U- & Ra- & $\mathrm{Pb}-$ & & $\mathrm{Bi}-$ & $\mathrm{Pb}-$ & Ac- & $\mathrm{Pb}-$ & $\mathrm{Bi}-$ & & TI- & $\mathrm{K}-$ & $\mathrm{Be}-$ \\
\hline Total & & 32 & 2 & & 0 & 7 & 9 & 9 & 34 & 37 & 99 & & 9 & 9 & 9 & 35 \\
\hline$Q<3000$ & ${ }^{3} \cdot 5^{-}$ & 12 & 1 & & 0 & 0 & 4 & 4 & 13 & 15 & 40 & & 3 & 4 & 4 & 14 \\
\hline$Q>3000$ & ${ }^{3} \cdot 5^{\circ}$ & 20 & & 9 & 0 & 7 & 5 & 5 & 20 & 21 & 59 & & 5 & 5 & 5 & 20 \\
\hline
\end{tabular}

Based on this dataset, Th-234, Bi-214, Ac-228, Bi-212 were preliminarily studied in order to highlight signatures or individual behaviour. Additional investigations are underway to characterise origins, fate and behaviour of naturally occurring radionuclides at the lower course of the Rhone River.

In the following discussion, the activities of Ra-226, Ra-228 and Th-228 are estimated from $\mathrm{Bi}-214$, Ac-228 and $\mathrm{Pb}-212$ gamma measurements, respectively, assuming that each of U-238 and Th-232 decay series in the SPM is in radioactive equilibrium.

\subsection{U-Th series disequilibrium: Th-234/Ra-226}

U-238 produces Th-234 and Ra-226 radionuclides by radioactive decay. Figure 4 shows the relationship between the activities of Th-234 and Ra-226, at low and 
high water discharge (i.e. below or over $3000 \mathrm{~m}^{3} . \mathrm{s}^{-1}$ ). If the Ra-226 was in radioactive equilibrium with its ascendant Th-234, the activities ratio Th-234/Ra226 should be equal to 1 and the relationship would be linear with a slope equivalent to 1 (figure in dotted line in Figure 4). The Th-234/Ra-226 activity ratio varies from $0.6 \pm 0.2$ to $2.4 \pm 0.9$. Even so, Figure 4 shows a radioactive disequilibrium between Ra-226 and Th-234, especially at low water discharge $\left(<3000 \mathrm{~m}^{3} . \mathrm{s}^{-1}\right)$. Does this radioactive disequilibrium reflect depletion in Ra-226 or enrichment of Th-234 in suspended sediments?

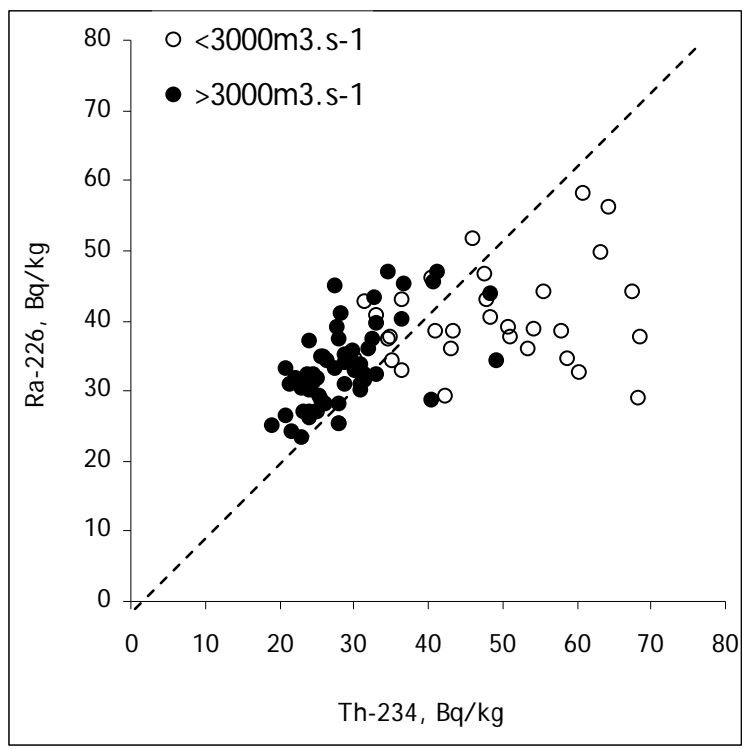

Figure 4: $\quad$ Ra-226 vs. Th-234.

\subsubsection{Depletion in Ra-226 hypothesis}

Assuming a Ra-226 deficit, the fractionation observed between Th-234 and Ra226 could be explained by the geochemical behaviour of Ra-226 in aquatic environments as radium is potentially soluble [19]. Therefore, such a fractionation would occur in the Th-232 series as well. Thus, assuming a geochemical fractionation favourable to the solubilisation of radium compared with thorium, the radioactive equilibrium between Ra-228 and its descendant Th228 could not be reached. Figure 5 shows the relationship between the activities of Ra-228 and Th-228. The observed linear relationship, with a slope equivalent to 1 , reflects the radioactive equilibrium between these two radionuclides.

Therefore, there is no evidence of geochemical fractionation in U-238 and Th-232 nuclide series due to the preferential solubilisation of radium compared with thorium. As a consequence, the radioactive disequilibrium between Th-234 and Ra-226 reflects rather an enrichment of Th-234 in suspended sediments. 


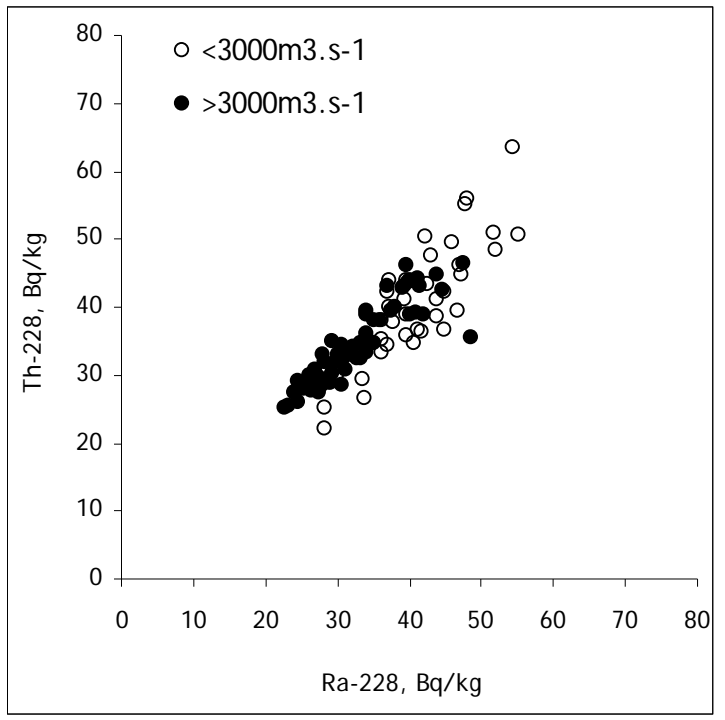

Figure 5: Th-228 vs. Ra-228

\subsubsection{Enrichment in Th-234 hypothesis}

What are the parameters that can affect the quantity of Th-234 present in suspended sediments?

Th-234 is a particle-reactive isotope while its parent, U-238, is generally nonreactive and known to be soluble and conservative in oxidized aquatic systems [19]. In the water column, Th-234 (half-life $24.1 \mathrm{~d}$ ) is continuously produced in situ from the decay of soluble U-238 and rapidly adsorbs onto particles: this well known mechanism leads to "excess Th-234". The longer a particle stays in the water column the more it will be enriched in excess Th-234. This was particularly observed in marine environments and used to estimate the residence time of particles in various aquatic systems including the open sea, estuaries or lakes [20].

In suspended sediments at the lower course of the Rhone River, Th-234 enrichment is observed mainly at low discharges as shown in Figure 4, and no significant shift from the 1:1 ratio has being observed for high discharges $\left(>3000 \mathrm{~m}^{3} \cdot \mathrm{s}^{-1}\right)$. So we suggest that suspended sediments mobilized in high flow conditions could therefore not stay long enough in water.

However, the hypothesis of an enrichment of Th-234 due to the radioactive liquid releases of $U$ from the nuclear industry authorised at low water discharge $\left(<4000 \mathrm{~m}^{3} . \mathrm{s}^{-1}\right)$ cannot be totally excluded. Radioactive waste effluents are generally characterised by specific isotopic signatures [21], so that isotopic measurements would give information about the origin of $U$ in the lower Rhone River. Recently, U isotopic analysis was conducted on flood sediments collected in the lower course of the Rhone River near the SORA observatory station. The 
$\mathrm{U}-234 / \mathrm{U}-238$ and $\mathrm{U}-235 / \mathrm{U}-238$ activity ratios were equal to $1.0 \pm 0.3$ and $0.046 \pm 0.011$ respectively, which are equivalent to ratio values attributed to naturally originated uranium, i.e. 1.00 and 0.046 respectively [22]. Therefore, in sediments, there is no evidence of uranium enrichment due to industrial radioactive effluents.

Th-234 enrichment observed at low water discharge could also be related to the U-Th fractionation in relation to weathering processes in the watershed [12]. Nevertheless, in suspended sediments of the lower Rhone, the activity ratio Ra226/Ra-228 ranges from 0.8 to 1.2 with a mean value of $0.96 \pm 0.10$ at low water discharge, and ranges from 0.7 to 1.4 with a mean value of $1.04 \pm 0.15$ at high water discharge. These values do not differ from the mean ratio U-238/Th-232 characterising the upper continental crust [23]. Thus, we conclude that weathering is not significantly involved in Th-234 enrichment.

Finally, Th-234 enrichment observed at low water discharge could be related to the nature and origin of the suspended solids. Suspended sediments represent a mixing of particles derived from mineralogical, biological or anthropogenic origins and act as transport vectors for radionuclides. The ability of particles to fix radionuclides in aquatic systems is mainly related to their physical and chemical properties that may hugely vary depending on various parameters including grain size, organic contents, mineralogical composition and living/non living particles.

\section{Conclusions}

Radioecological monitoring chronicles provide relevant data set to explore the variability of naturally occurring radionuclide contents in river systems. This was demonstrated from the data set acquired at the lower course of the Rhone River since 2000. Our first results from gamma ray measurements on suspended sediments gave evidence on Th-234/Ra-226 disequilibrium that can be linked to various parameters including the nature, origins and residence time of particles.

\section{Acknowledgements}

This work received the support of the French National Research Agency (ANR) through the ANR-EXTREMA project (contract NANR-06-VULN-005, 20072011) and from the competitive poles "Mer PACA" and "Gestion des Risques et Vulnérabilité des territoires” (Risk Management and Vulnerability of territories). Additional funding support has been provided by the “Agence de l'Eau RhôneMéditerranée-Corse” (Water Agency Rhône-Mediterranean-Corsica) and ZABROSR (Workshop area of the lower Rhone - Rhone Sediments Observatory). Liquid discharge data in Arles were available thanks to the CNR (Compagnie Nationale du Rhône). The authors gratefully acknowledge M. Fornier and S. Thomas for their analytical and field work. 


\section{References}

[1] Bluth G.J.S. and Kump L.R., 1994, Lithologic and climatologic controls of river chemistry, Geochimica et Cosmochimica Acta, 58, 2341-2359.

[2] Ollivier P., Radakovitch O. and Hamelin B., 2011, Major and trace element partition and fluxes in the Rhône River, Chemical Geology, 285, 15-31.

[3] Pont D., Simonnet J.-P. and Walter A.V., 2002, Medium-term changes in suspended delivery to the ocean: consequences of catchment heterogeneity and river management (Rhône River, France), Estuarine, Coastal and Shelf Science, 54, 1-18.

[4] Antonelli C., Eyrolle F., Rolland B., Provansal M. and Sabatier F., 2008, Suspended sediment and ${ }^{137}$ Cs fluxes during the exceptional December 2003 flood in the Rhone River, southeast France, Geomorphology, 95, 350-360.

[5] Ollivier P., Hamelin B. and Radakovitch O., 2010, Seasonal variations of physical and chemical erosion: A three-year survey of the Rhone River (France), Geochimica et Cosmochimica Acta, 74, 907-927.

[6] Sempéré R., Charrière B., Van Wambeke F. and Cauwet G., 2000, Carbon inputs of the Rhône River to the Mediterranean Sea: biogeochemical implications. Global Biogeochemical Cycles, 14, 669681.

[7] Eyrolle F., Charmasson S. and Louvat D., 2004, Plutonium isotopes in the lower reaches of the River Rhône over the period 1945-2000: fluxes towards the Mediterranean Sea and sedimentary inventories, Journal of Environmental Radioactivity, 74, 127-138.

[8] Ferrand E., Eyrolle F., Radakovitch O., Provansal M., Dufour S., Vella C., Raccasi G. and Gurrarian R., 2012, Historical levels of heavy metals and artificial radionuclides reconstructed from overbank sediment records in lower Rhône River (South-East France), Geochimica et Cosmochimica Acta, 82, 163-182.

[9] Provansal M., Ferrand E., Eyrolle F., Raccasi G., Monaco M. and Gurrarian R., 2012, Spatial variability in sedimentation rates and artificial radionuclide storage in alluvial banks of the lower Rhône River, Aquatic Sciences, in press.

[10] Eyrolle F., Louvat D., Métivier J.-M. and Rolland B., 2005, Origins and levels of artificial radionuclides within the Rhône river waters (France) for the last forty years: Towards an evaluation of the radioecological sensitivy of river systems, Radioprotection, 40, 4, 465-440.

[11] Eyrolle F., Claval D., Gontier G. and Antonelli C., 2008, Radioactivity levels in major French rivers: summary of monitoring chronicles acquired over the past thirty years and current status, Journal of environmental Monitoring, 10, 800-811.

[12] Eyrolle F., Radakovitch O., Raimbault P., Charmasson S., Ferrand E., Jacquet S., Aubert D., Raccasi G. and Gurrarian R., Consequences of hydrological events on suspended sediment and associated radionuclide 
deliveries from the Rhône River towards the Mediterranean Sea, Journal of Soils and Sediments, accepted, May 2012.

[13] Raimbault, P., Durrieu de Madron, X., 2003, Research activities in the Gulf of Lion (NW Mediterranean) within the 1997-2001 PNEC project, Oceanologica Acta, 26, 291-299.

[14] Rolland B., 2006, Transfert des radionucléides artificiels par voie fluviale: conséquences sur les stocks sédimentaires rhodaniens et les exports vers la Méditerranée. Thèse de l’Université Paul Cézanne d’AixMarseille, 243p.

[15] Antonelli C., 2002, Flux sédimentaires et morphogénèse récente dans le chenal du Rhône aval. Thèse de l'Université de Provence, Aix-enProvence, 272p.

[16] Ibanez C., Pont D. and Prat N., 1997, Characterization of the Ebre and Rhône estuaries: a basis for determining and classifying salt-wedges estuaries, Limnology and Oceanography, 42, 89-101.

[17] Eyrolle F., Antonelli C., Raimbault P., Boullier V. and Arnaud M., SORA: A high frequency flux monitoring station at the lower Rhône River. Proceedings of the $39^{\text {th }}$ CIESM Congress, Venice, Italy, 10-14 may 2010.

[18] Bouisset P. and Calmet D., 1997, Hyper Pur Gamma-Ray Spectrometry applied to low-level environmental sample measurements. Proceedings of the International workshop on the status of measurement techniques for the identification of nuclear signatures, Geel, Belgium, 25-27 February.

[19] Chabaux F., Bourdon B. and Riotte J., 2008, U-series Geochemistry in weathering profiles, river waters and lakes. In: Krishnaswami, S., Cochran, J.K. (Eds.), U/Th Series Radionuclides in Aquatic Systems. Radioactivity in the Environment, 13, 49-104.

[20] Waples J.T., Benitez-Nelson C., Savoye N., Rutgers van der Loeff M., Baskaran M. and Gustafsson, 2006, An introduction to the application and future use of ${ }^{234} \mathrm{Th}$ in aquatic systems. Marine Chemistry, 100, 166-189.

[21] Zettwoog P., Lemaître N., Bernard S. et Vauzelle Y., 1997, Utilisation de la signature isotopique des radionucléides relâchés par les mines et les usines de traitement de minerais d'uranium pour discriminer aux bas niveaux leur impact environnemental de celui de la radioactivité tellurique naturelle. Radioprotection, 32, 467-489.

[22] Jia G., Belli M., Sansone U., Rosamilia S. and Gaudino S., 2006, Concentration and characteristics of depleted uranium in biological and water samples collected in Bosnia and Herzegovina. Journal of Environmental Radioactivity, 89, 172-187.

[23] Porcelli D. and Swarzenski P.W., 2003, The behaviour of U- and Th series nuclides in groundwater and the tracing of groundwater. Reviews in Mineralogy and Geochemistry, 52, 317-361. 